\title{
EDUKASI KESEHATAN VAKSIN DAN PENERAPAN PROTOKOL KESEHATAN COVID-19 PADA MASYARAKAT DUSUN CENRANA DESA CARAWALI KABUPATEN SIDRAP
}

DOI: https://doi.org/10.33024/jkpm.v4i4.4500

\author{
Asnuddin ${ }^{1}$, Sri Sakinah ${ }^{2 *}$, Meriem Meisyaroh S3 , Sulkifli Nurdin ${ }^{4}$, Hasrul5, \\ Murtini ${ }^{6}$, Suparta ${ }^{7}$, Hasnah ${ }^{8}$ \\ SITKeS Muhammadiyah Sidrap
}

Disubmit: 10 Juni 2021 Diterima: 19 Juni 2021 Diterbitkan: 02 Agustus 2021

Email Korespondensi: ns.srisakinah@gmail.com²

\begin{abstract}
ABSTRAK
Salah satu jenis penyakit baru dan belum pernah terdeteksi maupun terindetifikasi dari manusia, yang kemudian diberikan nama Coronavirus Disease 2019 (COVID19). Prinsip pencegahan dan strategi pengendalian secara umum saat ini masih belum ada vaksin untuk mencegah infeksi covid-19. Cara terbaik untuk mencegah infeksi adalah dengan menghindari terpapar virus penyebab. Tujuan setelah penyuluhan, diharapkan masyarakat dapat mengetahui manfaat dari vaksin dan selalu menerapkan protokol kesehatan dapat mencegah virus covid 19. Adapun kegiatan yang dilakukan berupa penyuluhan kesehatan tentang vaksin dan penerapan protokol kesehatan di era New Normal. Terdapat peningkatan pengetahuan pada masyarakat dalam pencegahan penyakit covid-19 pada masyarakat Dusun Cenrana Desa Carawali. Dengan demikian, pemberian penyuluhan pada masyarakat tentang pencegahan penyakit virus Covid-19 berjalan dengan baik dan mendapatkan respon yang positif dari masyarakat dan pihak pemerintahan.
\end{abstract}

Kata Kunci : Edukasi, Vaksin, Protokol Kesehatan, dan Covid-19

\section{ABSTRACT}

One of the new types of disease and has never been detected or identified from humans, which was later given the name Coronavirus Disease 2019 (COVID19). There is currently no vaccine to prevent infection with COVID-19. The best way to prevent infection is to avoid being exposed to the virus that causes it. The goal after the counseling is is hoped that the public can know the benefits of vaccines and always apply health protocols to prevent the covid 19 virus. The activities carried out are in the form of health education about vaccines and the application of health protocols in the New Normal era. There is an increase in knowledge in the community in preventing covid-19 disease in the Cenrana Hamlet community, Carawali Village. Thus, the provision of counseling to the public about the prevention of the Covid-19 virus disease went well and received a positive response from the community and the government.

Keywords: Education, Vaccines, Health Protocols, and Covid-19 


\section{PENDAHULUAN}

Corona virus adalah keluarga besar virus Severe Acute Respiratory Syndrom (SARS) dan Middle East Respiratory Syndrom (MERS) (Sohrabi et al., 2020). Salah satu jenis penyakit baru dan belum pernah terdeteksi maupun terindetifikasi dari manusia, yang kemudian diberikan nama Coronavirus Disease 2019 (COVID19). Virus ini adalah jenis virus yang ditularkan dari hewan ke manusia, yaitu kelelawar dan kemudian dikonfirmasi bisa ditularkan melalui sesama manusia (Kemenkes RI, 2020). Sampel isolate dari pasien diteliti dengan hasil menunjukkan adanya infeksi coronavirus, jenis betacoronavirus tipe baru, diberi nama 2019 novel coronavirus (2019-nCoV) (Kannan, et.al.,2020). Seiring berjalannya waktu, jumlah kasus terus bertambah dan semakin banyak jumlah yang terinfeksi termasuk tenaga medis. Sehingga dapat dikonfirmasi bahwa transmisi pneumonia ditularkan dari sesama manusia. Persebaran virus yang sangat cepat menyebar masih misterius dan penelitian masih terus berlanjut (Rothan and Byarareddy, 2020). WHO menyatakan sebanyak 213 negara sudah melaporkan ditemukannya kasus Covid-19 di Negara mereka. Data tercatat sebanyak 4.417.903 kasus dengan

297.382 kematian dan tingkat pertumbuhan kasus baru sebesar $7 \%$ per hari di seluruh dunia (WHO, 2020). Khusus di Indonesia sendiri Pemerintah telah mengeluarkan status darurat bencana terhitung mulai tanggal 29 Februari 2020 hingga 29 Mei 2020 terkait pandemi virus ini dengan jumlah waktu 91 hari (Buana, 2020).

Prinsip pencegahan dan strategi pengendalian secara umum saat ini masih belum ada vaksin untuk mencegah infeksi covid-19. Cara terbaik untuk mencegah infeksi adalah dengan menghindari terpapar virus penyebab. Lakukan tindakan-tindakan pencegahan penularan dalam praktik kehidupan sehari-hari (Cheah et al, 2020). Cuci Tangan Pakai Sabun (CTPS) adalah salah satu tindakan sanitasi dengan membersihkan tangan dan jari-jemari menggunakan air dan sabun untuk menjadi bersih. Salah satu indikator dari Perilaku Hidup Bersih dan Sehat adalah Cuci Tangan Pakai Sabun. Hasil yang diharapkan adalah meningkatnya pengetahuan masyarakat tentang pentingnya cuci tangan pakai sabun untuk mencegah timbulnya berbagai penyakit serta meningkatkan kemampuan masyarakat untuk mencuci tangan (Sitorus, 2014). Menurut Sulaeman dan Supriadi (2020), selain membekali masyarakat dengan pengetahuan tentang Covid-19, perlu juga diberikan pengetahuan tentang kunci penting untuk terhindar dari penularan/transmisi virus Covid-19 yaitu pengetahuan tentang kesehatan dan pola hidup bersih dan sehat (PHBS) secara baik dan benar.

Memperhatikan penyebaran virus tersebut, upaya pencegahan yang dapat dilakukan pemerintah Indonesia salah satunya adalah dengan menghimbau masyarakat untuk menggunakan masker Kesehatan dengan meningkatkan kekebalan tubuh manusia dengan pemberian vaksin. Upaya lain yang hingga saat ini dilakukan penanggulangan penyebaran Covid-19 adalah melalui riset untuk menghasilkan vaksin. Berbagai Negara sedang berlomba-lomba untuk dapat menghasilkan vaksin, karena selain memang untuk penanggulangan pandemi, vaksin akan menjadi komoditi yang akan banyak dicari dan memiliki nilai ekonomi tinggi.

Memberikan edukasi kepada masyarakat sangat diperlukan pentingnya komunikasi yang efektif karena bisa membuat orang yang diberikan edukasi mengerti dengan informasi yang disampaikan. Komunikasi pada dasarnya adalah sebuah aktivitas antara dua orang atau lebih untuk saling berbagi 
informasi atau saling ertukar pikiran memberikan informasi atau pesan yang ditujukan kepada sang penerima pesan atau informasi (Hadi Muhammad, et.al 2020).

\section{MASALAH}

Kondisi ini sangat penting untuk mendapatkan perhatian karena sangat rentan dengan penyebaran wabah Covid-19 yang akhir-akhir ini menimbulkan keresahan seluruh lapisan masyarakat. Namun berkembanganya isu-isu yang kurang bertanggung jawab dapat menjadi permasalahan penting dalam program pengendalian wabah Covid-19 di kabupaten Sidereng Rappang pada khususnya. Minimnya pengetahuan dan pemahaman penduduk mengenai informasi yang valid tentang agen virus Corona dapat menimbulkan dampak sosial yang besar. Upaya pencegahan yang dapat dilakukan adalah dengan melakukan berbagai kegiatan, salah satunya adalah kegiatan penyuluhan untuk dapat memberikan data dan informasi yang ilmiah kepada seluruh lapisan masyarakat mengenai wabah virus corona di Indonesia dan kabupaten Sidenreng Rappang Pada Khususnya. Pengetahuan dan pemahaman yang ilmiah, akurat dan dapat dipercaya akan dapat membantu masyarakat untuk mudah melaksanakan himbuan dan arahan pemerintah guna menekan penyebaran Covid-19. Atas dasar inilah telah dilakukan kegiatan penyuluhan kesehatan untuk meningkatkan pengetahuan penduduk desa carawali agar dapat menghadapi dan melewati pandemic Covid-19 terutama perkantoran dan tempat umum.

\section{Solusi yang ditawarkan}

Kegiatan Pengabdian pada Masyarakat ini dilaksanakan selama 1 hari di desa carawali Kabupaten Sidenreng Rappang metode pendekatan yang dilakukan untuk membantu mitra dalam menyelesaikan permasalahannya adalah (1) Persiapan kegiatan pengabdian; (2) Penyuluhan dengan tema edukasi kesehatan vaksin dan penerapan protokol kesehatan pada masyarakat desa carawali. Persiapan kegiatan pengabdian meliputi koordinasi dengan mitra untuk pelaksanaan kegiatan pengabdian, musyawarah dengan kepala desa carawali, dan penyiapan tempat penyuluhan. Untuk memecahkan permasalahan yang dihadapi kelompok mitra dalam kegiatan pengabdian ini dirancang kegiatan yang terstruktur meliputi transfer pengetahuan teoritis mengenai agen virus Corona dan mekanisme transmisi/penularannya, upaya pencegahan dan bahaya infeksinya. Selain pemahaman teoritis, juga dilakukan pembagian masker serta hand sanitizer. Melakukan penyuluhan dengan mendatangi masyarakat baik itu d kantor, tempat umum atau di rumah warga, mengingat kami sulit untuk mengumpulkan warga. 


\section{Target Luaran}

Tema edukasi kesehatan vaksin dan penerapan protokol kesehatan pada masyarakat desa carawali pada masyarakat setempat mulai dari penyuluhan sampai dengan revitalisasi di desa carawali, Kabupaten Sidrap.

\section{METODE PELAKSANAAN}

\section{Tahap Pertama}

Tahap pertama merupakan perencanaan kegiatan yang akan dilakukan. Proses perencanaan meliputi identifikasi kebutuhan, identifikasi potensi dan kelemahan yang ada, menentukan jalan keluar dan kegiatan yang akan dilakukan, dan membuat pengorganisasian kegiatan. Kegiatan tahap pertama dimulai dengan survei lapangan desa carawali. Survei lapangan dilakukan oleh tim pengabdian. Tim pengabdian melakukan diskusi dengan tokoh masyarakat serta wali desa carawali Kabupaten Sidenreng Rappang.

\section{Tahap Kedua}

Tahap kedua merupakan pelaksanaan kegiatan pengabdian Pada Hari Ahad yang berupa solusi yang telah disetujui kepala desa carawali kabupaten Sidenreng Rappang. Pelaksanaan kegiatan dilakukan selama 1 hari. Pertama dilakukan penyuluhan dan pemeriksaan Kesehatan gratis.

\section{HASIL DAN PEMBAHASAN}

Proses pelaksanaan dalam kegiatan Penyuluhan dengan tema Edukasi Kesehatan Vaksin Dan Penerapan Protokol Kesehatan Covid-19 Pada Masyarakat Dusun Cenrana Desa Carawali Kabupaten Sidrap Sulawesi Selatan dan penanganan pencegahan virus corona (Covid-19) ini dilaksanakan pada tanggal 29 Maret 2021 Pelaksanaan penyuluhan ditujukan pada masyarakat, media dan alat yang disediakan berupa lembar balik dan leaflet dan penyampaian materi dengan menggunakan PPT, Proyektor serta di rangkaikan dengan pemeriksaan kesehatan, pada saat materi berakhir di berikan follow up ke masyarakat yang mengikuti penyuluhan dengan mudah mereka bisa menjawab pertanyaan-pertanyaan yang di berikan serta ada beberapa masyarakat memberikan pertanyaan terkait hal yang belum mereka pahami, kegiatan ini harapannya ke depan bisa dilaksanakan secara berkesinambungan karena memang lokasi kegiatan penyuluhan ini merupakan lokasi desa binaan prodi ilmu keperawatan. Berikut gambar pelaksanaan penyuluhan yang telah di lakukan: 

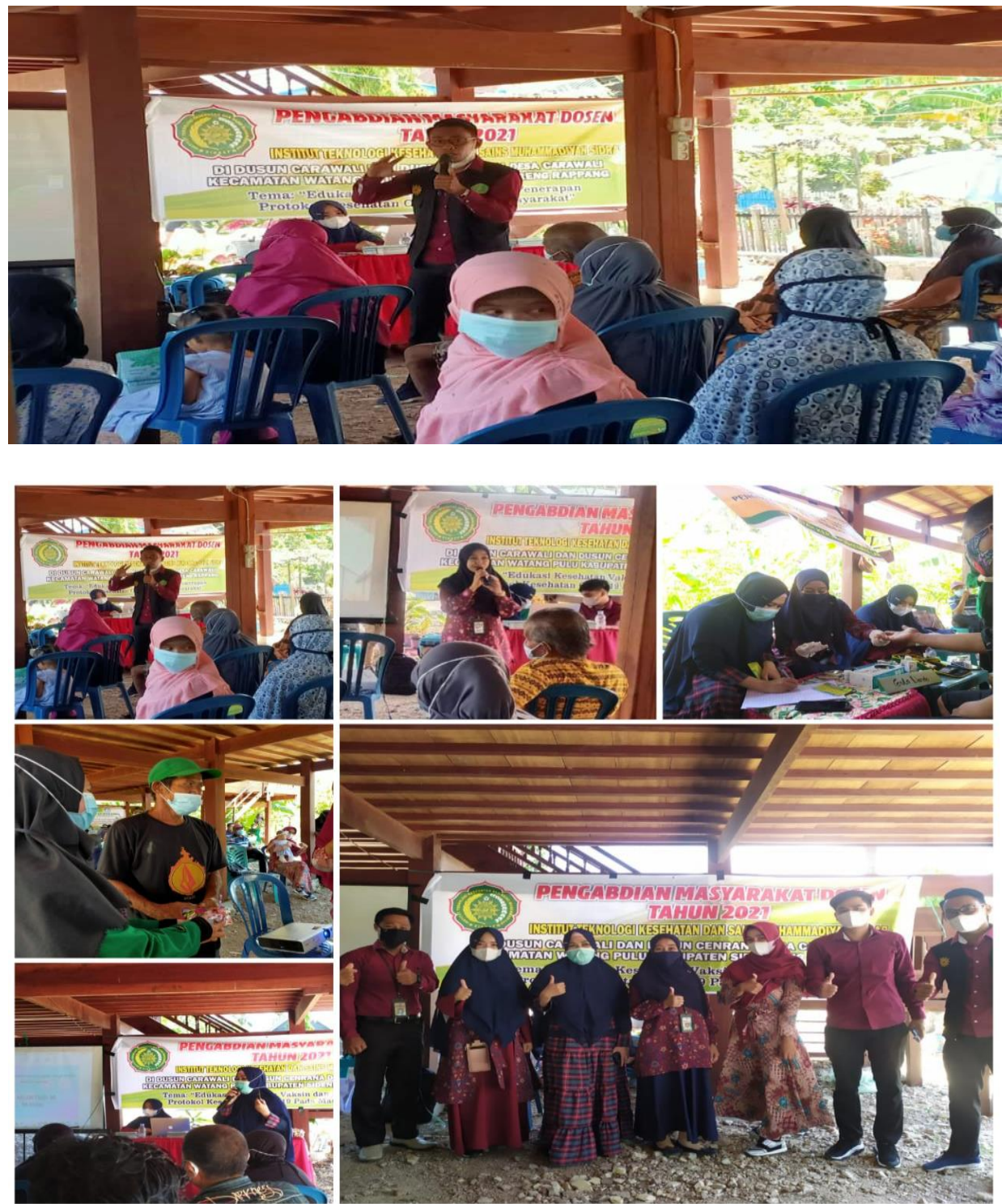

Gambar 4.1 Pelaksanaan Kegiatan PKM

\section{KESIMPULAN}

Kesimpulan yang diperoleh dari hasil kegiatan pengabdian masyarakat ini adalah; (1) Masyarakat dusun Cenrana desa Carawali telah mendapatkan penyuluhan dan penjelasan yang jelas dan mudah dipahami mengenai virus corona atau covid 19 yang sedang mewabah di berbagai Negara khususnya di indonesia; dan (2) Warga dusun Cenrana desa Carawali juga telah mendapatkan pengetahuan mengenai, peningkatan imun tubuh di masa pandemi, Pola Hidup Sehat dan Germas, Kesiapan Masyarakat dalam Menerima Vaksin. 


\section{DAFTAR PUSTAKA}

Buana, D. R. (2020). Analisis Perilaku Masyarakat Indonesia dalam Menghadapi Pandemi Virus Corona (Covid-19) dan Kiat Menjaga Kesejahteraan Jiwa. Salam: Jurnal Sosial dan Budaya Syar-i, 7(3), 217226.

Cheah, I. K., \& Halliwell, B. (2020). Could Ergothioneine Aid in the Treatment of Coronavirus Patients?. Antioxidants, 9(7), 595.

Hadi Muhammad, Nursalam M, Diah Priyantini. (2020), Buku Panduan Penanganan Covid-19 : Assesmen Cepat dan Penanganan Pasien Bagi Perawat dan Tenaga Kesehatan Dalam Memberikan Edukasi ke Masyarakat, Jakarta: UM Jakarta Press

Kannan, S., Ali, P. S. S., Sheeza, A., \& Hemalatha, K. (2020). COVID-19 (Novel Coronavirus 2019)-recent trends. Eur. Rev. Med. Pharmacol. Sci, 24(4), 2006-2011.

Kemenkes RI. (2020). Pedoman Pencegahan Pengendalian Coronavirus Disease (Covid 19)

Rothan, H. A., \& Byrareddy, S. N. (2020). The epidemiology and pathogenesis of coronavirus disease (COVID-19) outbreak. Journal of autoimmunity, 102433.

Sitorus, N., \& Fransisca, L. (2014). Pengaruh Pendidikan Kesehatan Terhadap Pengetahuan dan Sikap Cuci Tangan pakai Sabun pada Siswa SD Negeri 157 Kota Palembang Tahun 2014. JPP (Jurnal Kesehatan Poltekkes Palembang), 2(14).

Slamet et al. (2013). "Pedoman Umum Kesiapsiagaan Menghadapi Middle East Respiratory Syndrom-Corona Virus (MERS-CoV)," Jakarta, 2013

Sohrabi, C., Alsafi, Z., O'Neill, N., Khan, M., Kerwan, A., Al-Jabir, A., ... \& Agha, R. (2020). World Health Organization declares global emergency: A review of the 2019 novel coronavirus (COVID-19). International Journal of Surgery.

Sulaeman, S., \& Supriadi, S. (2020). Peningkatan Pengetahuan Masyarakat Desa Jelantik Dalam Menghadapi Pandemi Corona Virus Diseases-19 (Covid-19). Jurnal Pengabdian UNDIKMA, 1(1).

World Health Organization (2020). Novel Coronavirus (2019-nCoV). Citroner, G. Healthline. (2020). China Coronavirus Outbreak: CDC Issues Warning, Multiple Cases in U. 